\title{
Przestrzeń przemysłowa Szczecinka i Lęborka w układach regionalnych województwa pomorskiego i zachodniopomorskiego
}

W procesie transformacji polskiej przestrzeni coraz większą rolę odgrywa funkcjonowanie światowego systemu gospodarowania, którego istotę określa w coraz wyższym stopniu współzależność cywilizacji informacyjnej i globalizacji (Kołodziejski 1999). Wiąże się to przede wszystkim ze zmianą znaczenia i przewartościowaniem roli czynników decydujących o wyborze lokalizacji określonych funkcji społeczno-gospodarczych. Gospodarki miast, które są w stanie sprostać nowym wyzwaniom i dostosować się do nich, odnoszą wiele korzyści z globalizacji gospodarki, a ta staje się czynnikiem ich trwałego i zrównoważonego rozwoju. Z kolei miasta mniej strukturalnie dostosowane charakteryzują się mniejszą konkurencyjnością, czyli zdolnością sprostania nowym warunkom, co w konsekwencji prowadzi do pogłębiania się różnic w rozwoju miast (Chmielewski, Trojanek 1999).

Lokalizacja podmiotów gospodarczych uwarunkowana nowymi trendami globalizacji i konkurencyjności wyznacza ich określoną pozycję w hierarchicznym układzie regionalnym. Równocześnie obecne struktury regionalne zawierają w sobie wiele elementów z lat poprzednich, które w różnym stopniu są podatne na procesy transformacyjne (Zioło 1996). Województwa: pomorskie i zachodniopomorskie charakteryzują się wyższym niż przeciętnie $\mathrm{w}$ Polsce zatrudnieniem w sektorze przemysłowym, co w przypadku pomorskiego wynika z lokalizacji przemysłu zdominowanego przez pracochłonne dziedziny wytwórczości, natomiast w przypadku zachodniopomorskiego jest raczej strukturalną konsekwencją niewielkiego zatrudnienia w sektorze I, związanego ze specyfiką struktury agrarnej tego terenu (Geografia... 2004).

W miastach województw nadmorskich (podobnie jak w całym regionie) zarysowuje się tendencja ogólnego bezwzględnego spadku zatrudnienia w sektorze przemysłowym, co dało efekt zmiany udziału pracujących w przemyśle w stosunku do ogólnej liczby pracujących z 38,4\% w 1995 r. do 32,9\% w 2003 r. Udział pracujących w przemyśle maleje szczególnie w miastach dużych powyżej 100 tys. oraz średnich od 50 do 100 tys. mieszkańców (tab. 1). Należy przypuszczać, iż ubytek zatrudnienia w przemyśle wchłaniany jest przez rozwijające się szczególnie w dużych miastach usługi. Równocześnie należy pamiętać, że postępujący proces restrukturyzacji przemysłu prowadzi do dalszych redukcji zatrudnienia osób, które (szczególnie w okresie 1999-2002) częściej zasilają szeregi bezrobotnych, niż znajdują zatrudnienie w innym sektorze działalności. 
Tabela 1. Pracujący w sektorze przemysłowym w miastach województwa pomorskiego i zachodniopomorskiego w latach 1995-2003 (w \% ogółu pracujących)

\begin{tabular}{|l|c|c|c|c|c|c|c|c|c|}
\hline \multicolumn{1}{|c|}{ Miasta } & $\mathbf{1 9 9 5}$ & $\mathbf{1 9 9 6}$ & $\mathbf{1 9 9 7}$ & $\mathbf{1 9 9 8}$ & $\mathbf{1 9 9 9}$ & $\mathbf{2 0 0 0}$ & $\mathbf{2 0 0 1}$ & $\mathbf{2 0 0 2}$ & $\mathbf{2 0 0 3}$ \\
\hline razem & 38,40 & 37,75 & 37,89 & 37,27 & 36,65 & 36,20 & 35,30 & 33,69 & 32,97 \\
\hline 100 tys. i więcej & 36,65 & 35,49 & 35,16 & 34,53 & 33,72 & 32,92 & 32,23 & 30,31 & 28,76 \\
\hline 50-100 tys. & 46,18 & 45,19 & 45,45 & 43,92 & 42,72 & 36,11 & 39,11 & 35,42 & 36,04 \\
\hline 20-50 tys. & 39,57 & 39,35 & 40,13 & 40,25 & 40,15 & 40,95 & 39,40 & 38,29 & 38,22 \\
\hline poniżej 20 tys. & 40,12 & 40,73 & 41,49 & 40,45 & 40,55 & 41,22 & 39,63 & 37,32 & 37,66 \\
\hline
\end{tabular}

Źródło: Bank Danych Regionalnych, GUS, Warszawa

Szczególny obraz, a zarazem określenie intensywności zmian strukturalnych pracujących daje zastosowanie modelu przesunięć E.S. Dunna ${ }^{1}$. Wielkości dodatnie oznaczają większą dynamikę wzrostu danego elementu struktury w badanej jednostce przestrzennej w porównaniu z jednostką hierarchicznie wyższą, natomiast wielkości ujemne są równoznaczne ze słabszą dynamiką wzrostu danego elementu, a im wyższa wartość, tym tempo zmian silniejsze. Analiza przesunięć dyferencjalnych pracujących w sektorze przemysłowym w miastach regionów nadmorskich wykazała, iż 40\% jednostek charakteryzowało się mniejszą niż średnia dla miast dynamiką wzrostu udziału pracujących w sektorze przemysłowym, z tego największe wartości ujemne uzyskały miasta małe. W grupie tej znajdują się także dwa największe miasta regionów nadmorskich, tj. Gdańsk i Szczecin oraz 7 jednostek z grupy miast o liczbie mieszkańców od 20 do 50 tys., leżące w pasie nadmorskim (Świnoujście i Kołobrzeg) oraz w strefie wpływów aglomeracji trójmiejskiej (ryc. 1). Dynamikę wyższą niż przeciętna wykazywały miasta wszystkich kategorii wielkościowych, ale szczególnie skupione w południowej części województw pomorskiego i zachodniopomorskiego. Najbardziej stabilna wydaje się struktura pracujących w miastach o liczbie 20-50 tys. mieszkańców. W roku 1995 sektor przemysłowy zatrudniał przeciętnie w tych miastach 39,6\% ogółu pracujących i po okresie nieznacznego wzrostu w latach 1997-2000, ukształtował się w roku 2003 na poziomie 38,2\%. Przeprowadzona jednak szczegółowa analiza struktury pracujących w tej kategorii wielkościowej miast wskazuje na znaczne zróżnicowanie zachowania się tych jednostek w czasie.

W badanym okresie 1995-2003 można wyodrębnić trzy typy zachowań: wzrostu, stagnacji i spadku liczby pracujących w sektorze przemysłowym (tab. 2). Trudno jednoznacznie wskazać na przyczyny takich zachowań. Z jednej bowiem strony daje się zaobserwować wyraźny spadek pracujących w miastach o dominującej funkcji usługowej (np. Sopot - spadek z 27,8\% do 14,7\%, Kołobrzeg - spadek z 28,5\% do 21,3\%), z drugiej - znaczący wzrost w miastach przemysłowych (Kwidzyn - wzrost z 59,4\% do 67,4\%, Goleniów - z 45,6\% do $55,3 \%$ ), pozostaje jednak wiele jednostek (i tych o dobrze wykształconej funkcji przemysłowej, i takich, dla których przemysł jest funkcją uzupełniająca), gdzie można zaobserwować zmiany o różnym charakterze (np. duży spadek zatrudnienia w Policach, spadek, a następnie wzrost zatrudnienia w Malborku, czy wzrost zatrudnienia w Wałczu).

${ }^{1} \mathrm{~W}$ opracowaniu zastosowano model przesunięć dyferencjalnych działowych E.S. Dunna, celem porównania zmian udziałów pracujących w sektorze przemysłowym w poszczególnych miastach regionów nadmorskich ze zmianami tego podelementu struktury w jednostce wyższego rzędu, tj. wszystkich miastach regionów nadmorskich. Zastosowano wzór: $P_{d}=Z_{j}^{(t)}-Z_{j}^{(o)} \times \frac{Z_{j}^{(t)}}{Z^{(o)}}$ gdzie: $\mathrm{P}_{\mathrm{d}}$ - przesunięcia dyferencjalne działowe, $Z_{\mathrm{ij}}$ - wartość j-tej cechy w i-tej jednostce przestrzennej, $Z_{j}$ - wartość j-tej cechy w jednostce hierarchicznie wyższej, będącej bazą odniesienia, $Z^{(0)}$ - wartość cechy w wyjściowym momencie badanego okresu, $Z^{(t)}$ - wartość cechy w końcowym momencie badanego okresu (Runge 1992) 


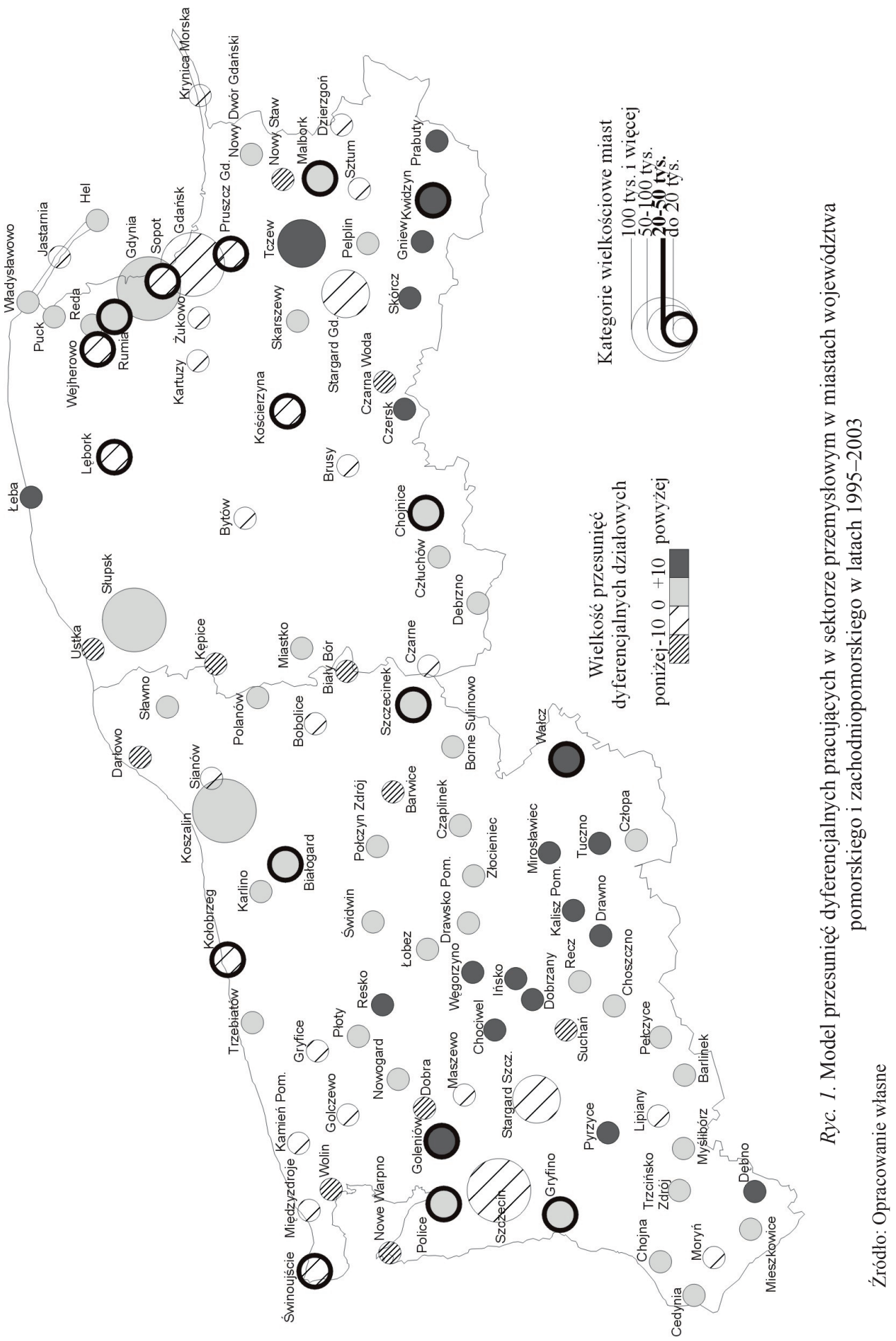


Tabela 2. Pracujący w sektorze przemysłowym w miastach średnich (20-50 tys. mieszkańców) województw pomorskiego i zachodniopomorskiego w latach 1995-2003 (w \% ogółu pracujących)

\begin{tabular}{|l|c|c|c|c|c|c|c|c|c|}
\hline \multicolumn{1}{|c|}{ Miasta } & $\mathbf{1 9 9 5}$ & $\mathbf{1 9 9 6}$ & $\mathbf{1 9 9 7}$ & $\mathbf{1 9 9 8}$ & $\mathbf{1 9 9 9}$ & $\mathbf{2 0 0 0}$ & $\mathbf{2 0 0 1}$ & $\mathbf{2 0 0 2}$ & $\mathbf{2 0 0 3}$ \\
\hline Białogard & 35,64 & 38,47 & 40,41 & 42,16 & 39,16 & 42,35 & 40,88 & 32,48 & 39,13 \\
\hline Chojnice & 49,96 & 50,71 & 49,75 & 46,39 & 46,69 & 46,74 & 44,50 & 44,09 & 45,30 \\
\hline Goleniów & 46,63 & 47,27 & 48,27 & 47,76 & 50,81 & 56,71 & 53,82 & 55,77 & 55,27 \\
\hline Gryfino & 31,89 & 33,44 & 36,34 & 33,56 & 39,64 & 25,34 & 22,32 & 29,12 & 27,66 \\
\hline Kołobrzeg & 28,51 & 27,58 & 26,31 & 25,26 & 26,63 & 29,00 & 25,57 & 23,58 & 21,28 \\
\hline Kościerzyna & 34,00 & 32,62 & 32,39 & 32,67 & 30,09 & 28,34 & 26,69 & 26,51 & 24,30 \\
\hline Kwidzyn & 59,40 & 57,82 & 60,21 & 62,21 & 63,39 & 64,22 & 61,84 & 62,46 & 67,42 \\
\hline Lębork & $\mathbf{4 2 , 6 2}$ & $\mathbf{4 4 , 8 8}$ & $\mathbf{4 6 , 8 3}$ & $\mathbf{4 9 , 4 0}$ & $\mathbf{4 6 , 8 6}$ & $\mathbf{4 5 , 7 8}$ & $\mathbf{4 0 , 6 2}$ & $\mathbf{3 3 , 7 9}$ & $\mathbf{3 3 , 3 5}$ \\
\hline Malbork & 34,27 & 34,95 & 34,36 & 33,37 & 31,27 & 30,29 & 33,06 & 33,47 & 33,88 \\
\hline Police & 66,98 & 65,34 & 65,38 & 65,62 & 66,66 & 67,39 & 62,93 & 61,07 & 60,21 \\
\hline Pruszcz Gdański & 50,88 & 52,78 & 55,91 & 54,47 & 52,91 & 50,03 & 45,80 & 44,01 & 40,84 \\
\hline Rumia & 46,72 & 46,37 & 49,30 & 48,62 & 45,64 & 47,41 & 46,92 & 45,99 & 41,76 \\
\hline Sopot & 27,82 & 26,10 & 24,17 & 21,75 & 22,84 & 19,35 & 18,84 & 15,90 & 14,71 \\
\hline Starogard Gdański & 56,89 & 55,17 & 54,02 & 51,96 & 50,67 & 49,22 & 46,09 & 44,46 & 42,47 \\
\hline Szczecinek & 39,12 & 39,85 & $\mathbf{4 1 , 0 1}$ & $\mathbf{4 3 , 7 5}$ & $\mathbf{4 2 , 0 2}$ & $\mathbf{4 3 , 8 8}$ & $\mathbf{4 5 , 2 6}$ & $\mathbf{4 5 , 1 7}$ & $\mathbf{4 3 , 2 7}$ \\
\hline Świnoujście & 23,99 & 21,85 & 22,66 & 21,30 & 20,10 & 18,26 & 17,76 & 15,43 & 16,06 \\
\hline Wałcz & 38,36 & 38,37 & 39,86 & 40,29 & 39,44 & 38,59 & 47,36 & 41,91 & 43,79 \\
\hline Wejherowo & 25,13 & 25,30 & 25,73 & 24,59 & 25,16 & 26,63 & 22,14 & 22,44 & 21,50 \\
\hline
\end{tabular}

Źródło: Bank Danych Regionalnych, GUS, Warszawa

Wpływ na taki stan rzeczy oprócz przekształceń o charakterze strukturalnym zdaje się mieć wielkość poszczególnych rynków pracy, dla których (w przypadku miast 20-50 tys. i mniejszych) likwidacja lub nowa lokalizacja jednego zakładu przemysłowego może pociągać za sobą widoczne zmiany struktury zatrudnienia. Dlatego w dalszej części artykułu dokonano szczegółowej analizy dwóch przypadków: Szczecinka, jako miasta cechującego się wzrostem liczby pracujących w przemyśle, i Lęborka, w którym w okresie 1995-2003 spadła liczba osób pracujących w tym sektorze działalności.

Dokonując analizy zmian liczby podmiotów gospodarczych w sektorze przemysłowym, możemy mówić o ich spadku w całej grupie miast województw nadmorskich (tab. 3). Przy czym spadek ten, w przypadku wszystkich kategorii wielkościowych miast, nie przekroczył trzech punktów procentowych. Analiza na poziomie poszczególnych jednostek osadniczych wykazała jednak różne tendencje zmian. W Szczecinku i Lęborku ukształtowała się bardzo podobna tendencja spadkowa, bowiem w obu tych miastach udział procentowy podmiotów gospodarczych sektora przemysłowego w ogólnej liczbie podmiotów zmniejszył się o około 6 punktów. Tendencja ta wynika nie tyle ze spadku liczby bezwzględnej podmiotów działających w sekcji D, ponieważ ta w obu przypadkach uległa zwiększeniu w analizowanym okresie, ile ze wzrostu udziału podmiotów gospodarczych w innych sekcjach. 
Tabela 3. Podmioty gospodarcze w sektorze przemysłowym w miastach województw pomorskiego i zachodniopomorskiego w latach 1995-2003 (w \% ogółu)

\begin{tabular}{|l|c|c|c|c|c|c|c|c|c|}
\hline \multicolumn{1}{|c|}{ Miasta } & $\mathbf{1 9 9 5}$ & $\mathbf{1 9 9 6}$ & $\mathbf{1 9 9 7}$ & $\mathbf{1 9 9 8}$ & $\mathbf{1 9 9 9}$ & $\mathbf{2 0 0 0}$ & $\mathbf{2 0 0 1}$ & $\mathbf{2 0 0 2}$ & $\mathbf{2 0 0 3}$ \\
\hline razem & 21,56 & 21,42 & 21,96 & 22,07 & 21,75 & 21,36 & 20,95 & 20,32 & 19,73 \\
\hline 100 tys. i więcej & 21,28 & 21,72 & 22,39 & 22,66 & 22,31 & 21,85 & 21,34 & 21,15 & 20,56 \\
\hline $50-100$ tys. & 22,38 & 21,77 & 22,98 & 23,59 & 23,74 & 24,02 & 24,02 & 19,64 & 18,96 \\
\hline 20-50 tys. & 22,78 & 22,25 & 22,40 & 22,05 & 21,92 & 21,58 & 21,05 & 20,43 & 19,90 \\
\hline poniżej 20 tys. & 20,80 & 19,53 & 19,97 & 20,00 & 19,47 & 19,22 & 19,10 & 18,31 & 17,74 \\
\hline Szczecinek & 23,17 & 21,88 & 21,12 & 19,36 & 17,65 & 17,31 & 17,49 & 17,05 & 16,72 \\
\hline Lębork & 27,37 & 24,97 & 24,47 & 24,46 & 24,00 & 23,72 & 22,39 & 22,27 & 21,85 \\
\hline
\end{tabular}

Źródło: Bank Danych Regionalnych, GUS, Warszawa

Wydaje się, że sytuacja taka wynikła z trudności restrukturyzacyjnych podmiotów przemysłowych w okresie transformacji, bowiem zasady konkurencyjności i wolnego rynku wymogły konieczność racjonalizacji ekonomicznych efektów, które najtrudniej wdrożyć w dużych przedsiębiorstwach. Jednak w Szczecinku struktura wielkościowa podmiotów prowadzących działalność przemysłową ma pewne uzasadnienie historyczne, bowiem w mieście tym osiągnięto stosunkowo wysoki poziom uprzemysłowienia już od końca lat sześćdziesiątych, budując przede wszystkim dużo drobnych zakładów przemysłowych, co objawiało się w ich dominacji, tzn. zakłady zatrudniające do 10 osób stanowiły prawie 70\% ogółu zakładów przemysłowych (Zdrojewski 1971). Struktura ta w pewnym stopniu znalazła swoje odzwierciedlenie w obecnej strukturze podmiotów gospodarczych.

Powodzenie w rozwoju sektora przemysłowego Szczecinka wynikać może także z jego atrakcyjności inwestycyjnej. Jak wskazują badania Instytutu Badań nad Gospodarką Rynkową z 2001 r. (Swianiewicz, Dziemianowicz 2001) Szczecinek na mapie inwestycyjnej miast powiatowych jawi się jako miasto o bardzo wysokiej atrakcyjności (klasa B), plasując się na 53 miejscu wśród 260 miast objętych badaniem. Z czynników wpływających na tę atrakcyjność najlepiej ocenione zostały: otoczenie biznesu, transformacja gospodarcza oraz klimat społeczny. W porównaniu z tym Lębork uplasował się dopiero na 92 pozycji w klasie $\mathrm{C}$ atrakcyjności inwestycyjnej, osiągając również bardzo dobry wynik w grupie czynników odpowiadających za transformację gospodarczą oraz stosunkowo dobry (klasa B) w przypadku klimatu społecznego.

W systemie miast regionów nadmorskich Szczecinek i Lębork już od wczesnych lat powojennych, kiedy na ziemiach tych kształtowała się polska gospodarka, ukierunkowywały się na rozwój sektora przemysłowego. Dobrym tego przykładem było uruchomienie na ziemi szczecineckiej w latach 1945-1946 ponad 30 zakładów przemysłowych i wzrost tej liczby do 80 w 1949 r. (Zdrojewski 1971). Na ziemi lęborskiej natomiast do końca 1947 r. uruchomiono 32 zakłady przemysłowe, zatrudniające ponad 1500 osób (Lindmajer, Machura 1982). O randze przemysłu w Szczecinku świadczyć może także fakt, że od 1960 r. powiat szczecinecki znalazł się na trzecim miejscu w województwie pod względem wielkości zatrudnienia w przemyśle (po Słupsku i Koszalinie) (Czarnik 1971). W kolejnych latach zarówno Szczecinek jak i Lębork wykazywały stałą tendencję wzrostu sektora przemysłowego, tak pod względem zatrudnienia, jak i ilości tworzących się nowych zakładów. W wyniku 
tego Szczecinek stał się wyspecjalizowanym ośrodkiem przemysłu drzewnego, spożywczego i elektrotechnicznego, a Lębork - przemysłu materiałów budowlanych, spożywczego i drzewnego.

Potwierdzeniem wysokiego poziomu uprzemysłowienia badanych miast jest klasyfikacja M. Jerczyńskiego z 1973 r. według dominacji funkcjonalnej, zgodnie z którą Szczecinek był przykładem miasta usługowo-przemysłowego, z przewagą usług materialnych, a Lębork przemysłowo-usługowego (z przewagą usług materialnych). Niemniej jednak w kolejnych latach zaznaczyła się tendencja do zmian wiodących funkcji omawianych miast, na co wskazują badania przeprowadzone przez E. Rydza (1998, 2001). Szczególnie wyraźne zmiany nastąpiły po 1990 r., a związane były z trwającym w Polsce okresem zmian systemowych i wprowadzeniem reguł gospodarki rynkowej. Transformacja wymogła na istniejących przedsiębiorstwach dokonanie szeregu przekształcen, co w wielu przypadkach skutkowało zmniejszeniem zatrudnienia, zmianą profilu działalności lub nawet upadłością. W nowych realiach struktura gospodarcza badanych ośrodków pozostała jednak w bardzo silnym stopniu uzależniona od sektora przemysłowego (w większym stopniu w Szczecinku niż w Lęborku). Uwidacznia się to chociażby większym niż przeciętna dla wszystkich miast regionów nadmorskich udziałem pracujących w sektorze przemysłowym (tab. 1).

Dla gospodarki miasta Szczecinka największe znaczenie posiadały zakłady przemysłu drzewnego. W latach pięćdziesiątych ta gałąź przemysłu reprezentowana była przez nowoczesną Fabrykę Płyt Wiórowych oraz liczne tartaki, a ich rozwój związany był w dużej mierze z bogactwem naturalnym, jakim są lasy, bowiem zaznaczyć należy, że lesistość powiatu szczecineckiego wynosi 43\%. Zakłady przemysłu drzewnego do dzisiaj stanowią ważny element gospodarki miasta. Branże te (drzewną i papierniczą) reprezentują obecnie Kronospan Holdings GK oraz Koszalińskie Przedsiębiorstwo Przemysłu Drzewnego S.A w Szczecinku, które wymieniane są jako jedne z najlepszych firm województwa zachodniopomorskiego pod względem przychodu oraz zatrudnienia ${ }^{2}$. Pierwsza $\mathrm{z}$ tych firm stanowi istotny element rynku pracy Szczecinka, zatrudnia bowiem ponad 600 osób (ogółem około 1800), natomiast druga z nich ponad 50 osób (ogółem około 1200). Zaznaczyć jednak należy, iż są to przedsiębiorstwa wielopunktowe, posiadające swoje zakłady i filie w różnych miejscach województwa, a nawet kraju, stąd ich bezpośredni wpływ na rynek pracy Szczecinka jest nieco mniejszy. Z branży papierniczej na uwagę zasługuje firma WZ Eurocopert Sp. z o.o., istniejąca od 1990 r., produkująca szeroki asortyment kopert oraz zatrudniająca blisko 200 osób.

Największym zakładem przemysłu spożywczego w Szczecinku była uruchomiona w 1954 r. Spółdzielnia Inwalidów „Słowianka”, produkująca wyroby cukiernicze, która zatrudniała wówczas około 200 osób. Firma ta rozwija się nadal, skutecznie wdrażając nowe technologie, czego wynikiem jest posiadanie obecnie trzech zakładów produkcyjnych na terenie miasta i zatrudnienie około 380 pracowników. Innym znaczącym zakładem z tej branży jest Elmilk Sp. z o.o. - zakład powstały na bazie Okręgowej Spółdzielni Mleczarskiej, zajmujący się produkcją wyrobów mlecznych i tłuszczowych i zatrudniający ponad 250 osób.

Przemysł elektrotechniczny rozwinął się na bazie Zakładów Sprzętu Instalacyjnego A-22, a obecnie reprezentowany jest przez spółkę ELDA-ELTRA Elektotechnika S.A., specjalizującą się w produkcji kompletnych akcesoriów dla elektrycznych instalacji budynków i zatrudniająca ponad 600 pracowników oraz TELZAS Sp. z o.o. - firmę, która powstała

${ }^{2}$ Według rankingu „Rzeczpospolitej” Lista 2000 - Polskie przedsiębiorstwa’ 2004 właśnie Kronospan w województwie zachodniopomorskim osiagnął najlepsze wyniki finansowe. „Rzeczpospolita” nr 299 z dnia 21.12.2004 r. 
w 1976 r., będącą wiodącym producentem i dostawcą systemów zasilania gwarantowanego dla aplikacji telekomunikacyjnych i teleinformatycznych (zatrudnia około 120 pracowników).

$\mathrm{Z}$ innych zakładów przemysłowych w Szczecinku, które posiadają duże znaczenie ze względu na wielkość zatrudnienia wymienić należy: Pomorski Ośrodek Maszynowy POMEKO Sp. z o.o. oraz Centrostal Przedsiębiorstwo Wielobranżowe S.A., działające w branży metalowej. Firma POM-EKO zajmuje się przede wszystkim produkcją różnego rodzaju kontenerów i pojemników metalowych, przyczep samochodowych, zabudowy samochodów i innych elementów metalowych i jest jedną z dynamiczniej rozwijających się w Szczecinku, z zatrudnieniem około 200 osób. Centrostal natomiast jest firmą zajmującą się przede wszystkim zaopatrywaniem w materiały i wyroby hutnicze. Firma rozpoczęła działalność jako jeden z 17 terenowych oddziałów Centrostalu, w 1997 r. została pomyślnie sprywatyzowana poprzez leasing pracowniczy, a od 2001 r. poważnie wzmocniona przez inwestora strategicznego Poland Alloys Sp. z o.o. Obecnie firma działa na terenie pięciu województw północno-zachodniej Polski z centralą w Szczecinku.

Przemysł lęborski w połowie lat pięćdziesiątych reprezentowały zakłady przemysłu spożywczego (46 zakładów, 831 zatrudnionych), przemysłu drzewnego (9 zakładów, 737 zatrudnionych), przemysłu materiałów budowlanych (8 zakładów, 358 pracowników) (Lindmajer, Machura 1982). Do najważniejszych zakładów zaliczano: Lęborskie Zakłady Przemysłu Drzewnego, Przedsiębiorstwo Materiałów Budowlanych w Lęborku reprezentowane przez 5 cegielni, Zakład Roszarniczy „Włóknolen”, Zakład Produkcji Torfowej, Spółdzielnię Pracy Metalowo-Odlewniczej im. Generała Świerczewskiego, Spółdzielnię „Wspólna Praca” działającą w branży skórzano-obuwniczej, Zakład Naprawczy Mechanizacji Rolnictwa czy Lęborskie Zakłady Przemysłu Terenowego, w skład których weszły: Państwowa Stolarnia Mechaniczna Nr 3, tartak oraz Wytwórnia Wyrobów Skórzanych i Podróżniczych. W kolejnych latach następowały pewne zmiany w strukturze przemysłowej Lęborka. Pojawiły się zakłady o bardziej zaawansowanych technologiach, jak Zakłady Wytwórcze Aparatury Rozdzielczej (1965), które przekształciły się w przedsiębiorstwo o znaczeniu kluczowym. Uruchomiony został ponadto w 1969 r. Zakład Remontu Maszyn Budowlanych ZREMB. Znaczenie Lęborka wynikało także z niewielkiej odległości od wybrzeża Morza Bałtyckiego i jego powiązań z Łebą. Gospodarczym przejawem tych związków było powstanie w Lęborku w bezpośredniej bliskości linii kolejowej Zakładów Przetwórstwa Rybnego „Krabbpol”. Współcześnie w branży spożywczej, zajmującej się przetwórstwem rybnym, największe znaczenie dla sektora przemysłowego posiada oprócz wymienionej firmy „Krabbpol”, spółka LAURIN SEAFOOD, utworzona w 1999 r., czy firma DOS Sp. z o.o. produkująca konserwy, ryby mrożone i wędzone. Wymienić w tym miejscu należy także firmę Farm Frites Poland S.A., będącą przykładem udanego wykorzystania kapitału zagranicznego, zajmującą się produkcją frytek i innych wyrobów ziemniaczanych. Powstała w 1994 r. fabryka w Lęborku jest jedną z najnowocześniejszych wytwórni frytek w Europie, zatrudnia obecnie około 180 osób, ale jej znaczenie dla rynku pracy i gospodarki lokalnej jest znacznie szersze. Wiąże się to przede wszystkim z wykorzystaniem urodzajnych gleb Wysoczyzny Damnickiej, gdzie uprawia się specjalne odmiany ziemniaka na powierzchni 1000 ha przez specjalnie do tego celu utworzoną firmę Farm Frites Dwa. Ponadto fabryka wykorzystuje surowiec z farm poddostawców, uprawiających ziemniaki na kolejnych 3 tys. ha, przyczyniając się także do rozwoju rolnictwa tego obszaru. 
Na uwagę zasługują również zakłady produkujące materiały budowlane, a szczególnie powstała na bazie lęborskich cegielni firma Wienerberger Cegielnie Lębork Sp. z o.o. Firma rozpoczęła działalność w 1995 r. poprzez modernizację cegielni i wprowadzanie nowoczesnych technologii do produkcji cegieł i pustaków. Rozwijająca się szybko fabryka posiada obecnie 19 zakładów produkcyjnych w Polsce i zatrudnia około 2 tys. osób.

W Lęborku mocno reprezentowana jest również branża metalowa. Produkcją kontenerów i konstrukcji stalowych zajmuje się Przedsiębiorstwo Produkcyjno-Handlowe AMG Sp. z o.o. (utworzone w 1991 r. i zatrudniające około 180 osób) oraz Przedsiębiorstwo Zagraniczne ROBEX. Maszyny i konstrukcje ze stali nierdzewnej dla przemysłu spożywczego wytwarza natomiast powstała w 1996 r. firma „Numafa Polska” Sp. z o.o. Z powodzeniem rozwija się również Odlewnia Żeliwa i Metali Nieżelaznych „SPOMEL”, która jest kontynuatorką powstałej w latach pięćdziesiątych Spółdzielni Metalowo-Odlewniczej.

$\mathrm{Z}$ innych zakładów produkcyjnych należałoby wymienić: z branży drzewno-papierniczej - Przedsiębiorstwo Przemysłu Drzewnego POLTAREX (producenta tarcicy budowlanej i wagonowej, desek podłogowych, boazerii itp.) oraz Company LTD Sp. z o.o. (produkcja opakowań z drewna); z branży elektrotechnicznej - Zakład Wytwórczy Aparatów Elektrycznych Sp. z o.o. (aparatura rozdzielcza wysokiego i średniego napięcia); z branży chemicznej - Przedsiębiorstwo Produkcji Farmaceutyczno-Kosmetycznej PROFARM (produkcja leków i kosmetyków), czy BO-PLAST Zakład Produkcyjno-Usługowy (produkcja wyrobów izolacyjnych z tworzyw termoutwardzalnych, wyrobów z tworzyw termoplastycznych itp.).

Omówione zakłady przemysłowe należą do największych i przejawiających najbardziej dynamiczny rozwój w okresie transformacji systemowej. Specyfika gospodarki zarówno Lęborka jak i Szczecinka polega jednak przede wszystkim na istnieniu dużej ilości firm małych i średnich. Ich kondycja i rozwój w wielu przypadkach uzależnione są od kondycji tych większych przedsiębiorstw. Efekt mnożnikowy dużych inwestycji, lokowania kapitału zagranicznego umożliwia powstawanie małych i średnich firm kooperantów, czy otoczenia biznesu, a w dalszej kolejności obsługi społeczności lokalnej.

Omawiając kondycję sektora przemysłowego poddano szczegółowej analizie zlokalizowane w badanych miastach podmioty gospodarcze. W wyniku badań terenowych zewidencjonowano 59 zakładów zajmujących się działalnością produkcyjną w Szczecinku oraz 32 w Lęborku. Zakłady te poddano badaniom ankietowym, z czego 50\% zakładów w Szczecinku i 40\% w Lęborku odmówiło wzięcia udziału w badaniu. Uzyskane wyniki upoważniają jednak do dokonania pewnego rodzaju analiz pozwalających na uogólnienia.

Z punktu widzenia działań przystosowujących podmioty gospodarcze do wolnego rynku wydaje się istotne jak długo pozostają na nim zakłady działające w sektorze przemysłowym. Z przeprowadzonych badań wynika, iż w Szczecinku i Lęborku ok. 35\% zakładów powstało przed rokiem 1989. Spośród zakładów nowych, tj. rozpoczynających swoją działalność w okresie transformacji gospodarczej, dużą część stanowią te, które założono w latach dziewięćdziesiątych. W Szczecinku podmioty te stanowiły około $40 \%$ badanego zbioru, natomiast w Lęborku aż 65\%. Gwarantuje to pewnego rodzaju stałość gospodarki oraz świadczy o stosunkowo pozytywnych procesach przystosowujących przedsiębiorstwa przemysłowe do zasad konkurencyjności i wolnego rynku.

Analizowane podmioty przemysłowe w całości reprezentowały prywatny sektor własności, deklarując jednocześnie całoroczny cykl produkcji. Zauważono jednak częściową zmienność sezonową produkcji. Zwiększone zapotrzebowanie na produkty w sezonie letnim 
w bardzo dużym lub znacznym stopniu zauważa około 15\% zakładów w Szczecinku i ponad 20\% w Lęborku, a dotyczą one głównie branży spożywczej i odzieżowej. Z drugiej strony nieco ponad 5\% zakładów w obu miastach określiło, że spada zapotrzebowanie na produkcję oferowanych przez nich produktów. Pozostała największa grupa firm nie zauważa (bądź tylko w nieznacznym stopniu) wzrostu zapotrzebowania w sezonie letnim. Ta stałość procesu produkcyjnego może tylko dodatnio wpłynąć na wyniki finansowe firm, ponieważ ich zyski nie są w dużym stopniu uzależnione od koniunktury sezonowej. Ma to szczególne znaczenie dla małych i średnich firm, które niezaprzeczalnie są ważnym elementem sektora przemysłowego Szczecinka i Lęborka. Badane firmy w ponad 65\% w Szczecinku zatrudniały do 5 osób, 10\% określiło zatrudnienie w granicach 6-10 osób oraz 25\% - powyżej 20 osób, przy czym większość deklarowała zatrudnienie w granicach 30-60 osób, a tylko nieliczne, jak wspomniana wcześniej ELDA-ELTRA czy Koszalińskie Przedsiębiorstwo Przemysłu Drzewnego - kilkaset osób. Bardzo podobna struktura podmiotów według zatrudnienia występowała w Lęborku, przy czym podmioty najmniejsze stanowiły ponad $73 \%$.

Dla określenia przyszłych perspektyw rozwoju sektora przemysłowego ważne wydaje się pytanie o charakter dalszej działalności (ryc. 2). Bardzo znaczące jest, że około 55\% firm ze Szczecinka i 68\% z Lęborka nie planuje dokonania żadnych zmian - poszerzania działalności bądź jej ograniczania.

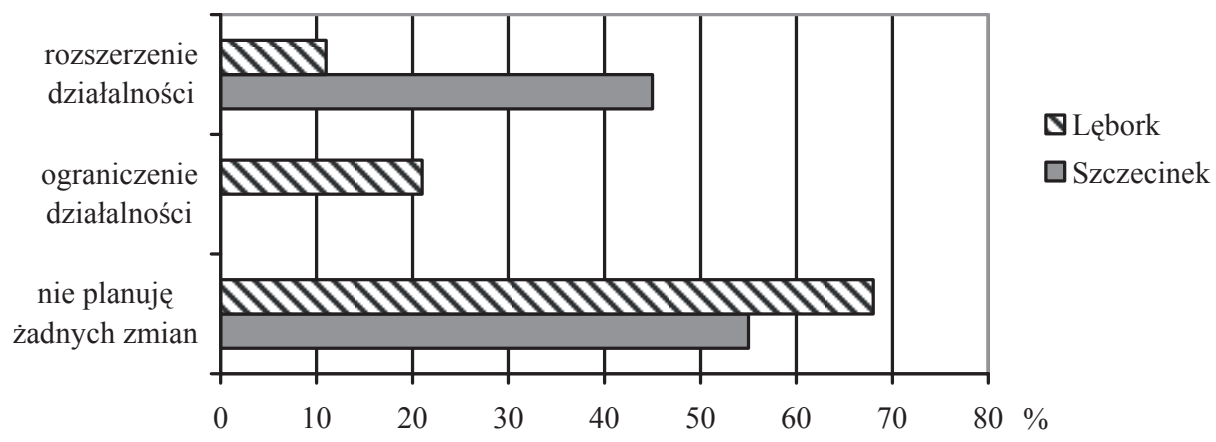

Ryc. 2. Ocena perspektyw działalności zakładów przemysłowych w Szczecinku i Lęborku w 2003 r.

Źródło: Opracowanie własne na podstawie badań ankietowych przeprowadzonych w Szczecinku i Lęborku w 2003 r.

Niepokojące natomiast wydaje się niezadowolenie ze swojej działalności ponad 20\% firm w Lęborku, które planują ograniczenie produkcji lub nawet likwidację firmy. W Szczecinku nie było takiej sytuacji, a 45\% zakładów przemysłowych deklarowało rozszerzenie działalności i dalszy rozwój. W Lęborku takich pozytywnie nastawionych firm było zaledwie 10\%. W miejscu tym uwidacznia się, akcentowana wcześniej, słabnąca rola sektora przemysłowego w Lęborku i - z drugiej strony - wzrost jego znaczenia w Szczecinku.

Z przeprowadzonych badań wynika z całą pewnością, że sektor przemysłowy, pomimo utraty swego znaczenia w Lęborku, nadal będzie stanowił ważny element gospodarki lokalnej miast średniej wielkości. 


\section{Literatura}

Chmielewski R., Trojanek M., 1999, Czynniki określajace konkurencyjność układów przestrzennych (regionów i miast), [w:] R. Domański (red.), Podstawy gospodarczej polityki miasta. Studium Poznania - część II, Biuletyn KPZK PAN, z. 187, Warszawa, s. 59-77.

Czarnik A. (red.), 1971, Dzieje ziemi szczecineckiej, Poznań.

Geografia gospodarcza Polski, 2004, pod red. I. Fierli, Warszawa.

Jerczyński M., 1973, Studia nad struktura funkcjonalnq miast, „Prace Geograficzne” 97, IGPAN.

Kołodziejski J., 1999, Nowa rola Poznania $w$ procesie przeksztatceń polskiej przestrzeni, [w:]

R. Domański (red.), Podstawy gospodarczej polityki miasta. Studium Poznania-część II, Biuletyn

KPZK PAN, z. 187, Warszawa, s. 95-108.

Lindmajer J., Machura T., (red.), 1982, Dzieje Lęborka, Poznań.

Runge J., 1992, Wybrane zagadnienia analizy przestrzennej w badaniach geograficznych, Katowice.

Rydz E., 1998, Przeksztatcenia struktur funkcjonalno-przestrzennych w regionach nadmorskich, Studia Geograficzne, 69, Uniwersytet Wrocławski, Wrocław, s. 195-213.

Rydz E., 2001, Miasta regionów nadmorskich w okresie transformacji systemowej, Zeszyty Naukowe, 5, Instytut Kształcenia Managerów, Zachodniopomorska Szkoła Businessu, Kołobrzeg, s. 5-20.

Swianiewicz P., Dziemianowicz W., 2001, Atrakcyjność inwestycyjna miast powiatowych, Instytut Badań nad Gospodarką Rynkową, Warszawa, http://gdansk.ibngr.edu.pl/news/konfera1.htm

Zdrojewski E.Z., 1971, Rozwój przemystu w latach 1945-1968, [w:] A. Czarnik (red.), Dzieje ziemi szczecineckiej, Poznań, s. 214-222.

Zioło Z., 1996, Przemiany struktur regionalnych w procesie transformacji systemu gospodarowania, Acta Universitatis Wratislaviensis nr 1814, Studia Geograficzne LXV, Wrocław, s. 89-97.

\section{The industrial area of Szczecinek and Lębork in regional structure of the Pomorskie and Zachodniopomorskie Voivodeships}

During the years of economic transformation there have been changes in regional industrial structures, which are strictly connected with the modification of meaning and overestimation of the role of elements decisive in choosing the location of some social-economic functions. The article presents the structure's characteristics of workers in the cities of Pomorskie and Zachodniopomorskie Voivodeships, with particular consideration of mid-cities. The sampler of differential workers' displacements in the industrial section pointed at diverse maintenance of cities in the years 1995-2003. It was noted that $40 \%$ of entities are characterized by lower than cities-average dynamism of the increase in the workers' participation in the industrial section. The lowest values were reached by small cities. This group includes also two largest cities of the littoral regions, i.e. Gdańsk and Szczecin, and 7 entities from the group of cities with 20-50 thousand inhabitants, located on the coast (Świnoujście and Kołobrzeg) and in the zone of influence of the Tricity agglomeration. The cities of all sizes were showing higher dynamics than the average, but especially those concentrated in the south part of the Pomorskie and Zachodniopomorskie Voivodeships. Mid-cities were characterized by three types of maintenance: increase, stagnation and decrease in the amount of workers in the industrial section, as a result of structural modification as well as the size of several work-markets, for which the liquidation or new location of one factory may implicate prominent changes in the structure of population. Therefore two cases have been elaborated in the subsequent section of the article: the first is Szczecinek, as a city with an increasing amount of workers, and the second is Lębork, where the index of industrial workers was increasing, and where during the period of time from 1995 to 2003 the number of people working in that field finally decreased. 